HortSCIENCE 26(1):23-25. 1991.

\title{
Chemical Desiccation of Onions for Set Production
}

\author{
John B. Masiunas \\ Department of Horticulture, University of Illinois, 1103 West Dorner \\ Drive, Urbana, IL 61801 \\ Additional index words. Allium cepa, diquat, lactofen, paraquat, emergence
}

\begin{abstract}
Experiments determined the effectiveness of the bipyridinium herbicides paraquat and diquat and of the diphenyl ether herbicide lactofen to desiccate onion (Allium cepa L.) shoots without affecting bulb quality and storage life. Paraquat, applied once, desiccated $80 \%$ of onion shoots within 3 days. Diquat desiccated $\approx 60 \%$ of onion shoots within 10 days of treatment. Lactofen caused slight necrosis but did not adequately desiccate onion shoots. Diquat and paraquat reduced sprouting of 'Red Wethersfield' more than of 'White Portugal'. Chemical names used: 6,7-dihydrodipyrido[1,2- $\alpha$ : 2',1'-c] pyrazinediium ion (diquat); ( \pm )2-ethoxy-l-methyl-2-oxoethy1 5-[2chloro-4-(trifluoromethyl)phenoxyl] -2-nitrobenzoate (lactofen); 1,1'-dimethyl-4,4'-bipyridinium ion (paraquat).
\end{abstract}

Onion sets are small, undersized bulbs that produce a large onion upon planting (Comin, 1946). Bulb size and storage life are important in onion set production. U.S. Dept. of Agriculture standards require a diameter of

Received for publication 23 Apr. 1990. Thanks to R. Lindstrom and W. Shoemaker for their technical assistance and to the Dutch Valley Growers, Inc., for donating the onion seed. Mention of a trade name does not constitute a guarantee of the product or an endorsement by the Univ. of Illinois over products not mentioned. The cost of publishing this paper was defrayed in part by the payment of page charges. Under postal regulations, this paper therefore must be hereby marked advertisement solely to indicate this fact.
0.8 to $2.5 \mathrm{~cm}$, with at least $40 \%$ of the sets between 0.8 and $1.9 \mathrm{~cm}$. Onion bulb size and storage life are affected by seeding rates and environmental conditions during growth. Excess moisture in the field can prolong maturation (Nonnecke, 1989), resulting in onion shoots remaining green and making harvesting difficult. Excess moisture also prevents sets from maturing properly, which reduces storage life (Comin, 1946; Nonnecke, 1989). Wet weather and high humidity during harvest and curing can lead to neck rot and premature sprouting (Walker et al., 1944).

Traditionally, to facilitate harvest, onion tops were treated with dinoseb [2-sec-butyl4-6-dinitrophenol]. In 1986, the U.S. Envi- 

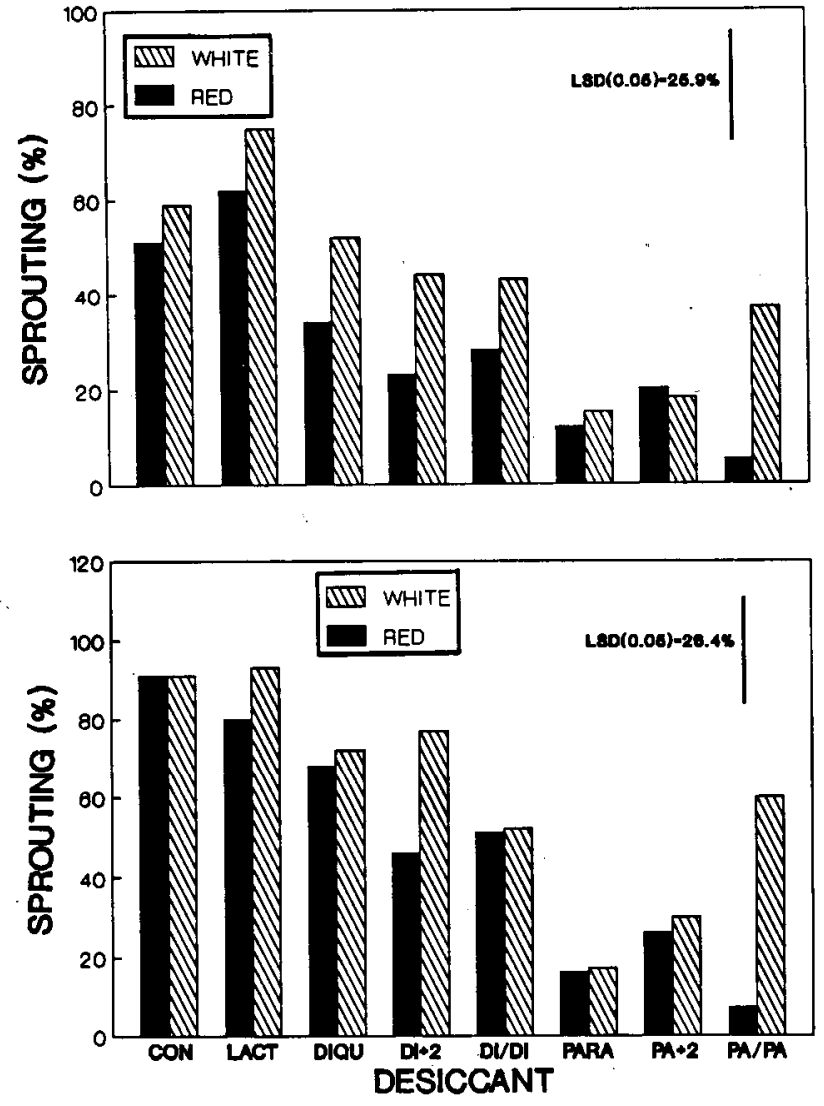

Pig. 1. Sprouting of onion shoots 3 weeks (top) and 5 weeks (bottom) after planting. The shoots were treated with a desiccant, the bulbs harvested and stored at SC for 4 months before being planted. The bars are means for 1987 and 1988 results. White = 'White Portugal'; red = 'Red Wethersfield'. The desiccant treatments were: untreated control $(\mathrm{CON})$; lactofen at $0.56 \mathrm{~kg} \cdot \mathrm{ha}^{-1}$ (LACT); diquat at $0.28 \mathrm{~kg} \cdot \mathrm{ha}^{-1}$ (DIQU); diquat at $0.28 \mathrm{~kg} \cdot \mathrm{ha}^{-1}$ plus UAN at 3.8 liter. ha ${ }^{-1}(\mathrm{DI}+2)$; two applications of diquat at $0.28 \mathrm{~kg} \cdot \mathrm{ha}^{-1}(\mathrm{DI} / \mathrm{DI})$; paraquat at $0.28 \mathrm{~kg} \cdot \mathrm{ha}^{-1}(\mathrm{PAM})$; paraquat at $0.28 \mathrm{~kg} \cdot \mathrm{ha}{ }^{-1}$ plus $\mathrm{UAN}$ at 3.8 liter $\cdot \mathrm{ha}^{-1}(\mathrm{PA}+2)$; and two applications of paraquat at $0.28 \mathrm{~kg} \cdot \mathrm{ha}{ }^{-1}(\mathrm{PA} / \mathrm{PA})$.

Table 1. Desiccation of 'Red Wethersfield' and 'White Portugal' onion foliage 10 days after the first treatment and the percent of onion sets regraded as U.S. no. 1 after 4 months of storage at 5 C. Data are means for 1987 and 1988.

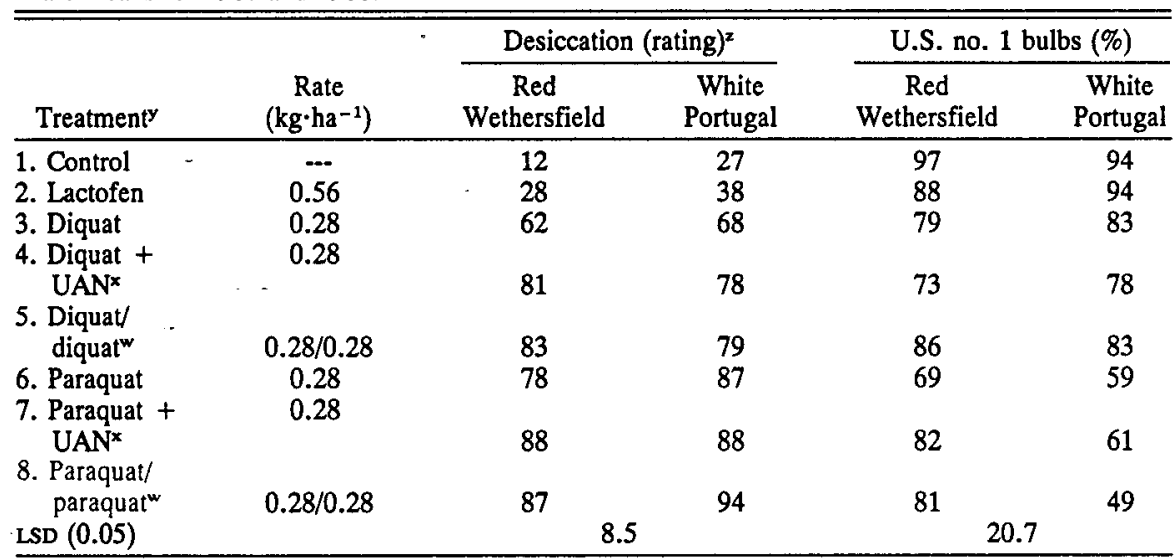

${ }^{2}$ Where $0=$ no foliar burn or senescence and $100=$ complete foliar burn and tissue death.

${ }^{y}$ All treatments but the control include X-77 at $470 \mathrm{ml} \cdot \mathrm{ha}^{-1}$.

xUAN was included at 3.8 liter $\cdot \mathrm{ha}^{-1}$.

wA second application was made 3 days after the first one.

ronmental Protection Agency canceled the registration for dinoseb, and there are no desiccants currently registered for onions. Paraquat and diquat (bipyridinium herbicides) are used to desiccate potato vines and may have potential for use in onion if they do not injure the bulb or cause residue problems. aka et al., 1986). Paraquat movement also was reported in radish (Raphanus sativus L.) and wild oats (Avena fatua L.) (Merritt, 1982). Plants do not metabolize bipyridinium herbicides. Residues of bipyridinium herbicides have been found in potato tubers even after several months of storage (Headford and Douglas, 1987; Summers, 1980). If diquat or paraquat translocates into the onion bulb, injury of the shoot meristem could result.

The translocation of bipyridinium herbicides in susceptible species causes concern about their use as onion desiccants. Thus, my objective was to determine the effectiveness of chemical desiccants to kill onion shoots while maintaining bulb storage life and viability.

The experiment was conducted in 1987 at Lansing, Ill., on a Milford silty loam soil (pH 5.8, organic matter $2 \%$ to $3 \%$ ) and in 1988 at St. Charles, 111., on Drummer silt loam soil ( $\mathrm{pH} \mathrm{6.2,} \mathrm{organic} \mathrm{matter} 4 \%$ to $5 \%$ ). 'Red Wethersfield' and 'White Portugal' onions were seeded on 20 Apr. 1987 and 10 May 1988. There were two rows of onions planted $10 \mathrm{~cm}$ apart per bed, and the plot size was $1.2 \times 3 \mathrm{~m}$. A seeding rate of 85 $\mathrm{kg} \cdot \mathrm{ha}^{-1}$ was used (Hopen and Peterson, 1974). The experiment was a split-plot design with the cultivars as main plots and desiccant treatment as subplots. There were three replications. DCPA [dimethyl 2,3,4,5,6-tetrachloro-1,4-benzenedicarboxylate] at 11.8 $\mathrm{kg}$ a.i./ha was applied at planting. Oxyfluorfen [2-chloro-1-(3-ethoxy-4-nitrophenoxy)-4(trifluoro-methyl)benzene] at $0.14 \mathrm{~kg}$ a.i./ha was applied for broadleaf weed control when the onions were at the two-to three-leaf stage. The experiment was maintained weed-free by cultivation and hoeing as necessary. Chlorothalonil [tetra-chloroisophthalonitrile] and azinphos-methyl [o,o-dimethyl s-(4 oxo1,2,3 -benzotriazin-3 - $(4 \mathrm{H})$-yl methyl) phosphorodithioate] were applied as needed to control diseases (i.e., Botrytis leaf blight and purple blotch) and insects (thrips), respectively.

The desiccant treatments were: 1) an untreated control; 2) lactofen at $0.56 \mathrm{~kg} \cdot \mathrm{ha}{ }^{-1}$; 3) diquat at $0.28 \mathrm{~kg} \cdot \mathrm{ha}^{-1}$; 4) diquat at 0.28 $\mathrm{kg} \cdot \mathrm{ha}^{-1}$ plus urea ammonium nitrate (UAN) at 3.8 liter $\cdot \mathrm{ha}^{-1}$; 5) two applications of diquat at $0.28 \mathrm{~kg} \cdot \mathrm{ha}^{-1}$; 6) paraquat at 0.28 $\mathrm{kg} \cdot \mathrm{ha}^{-1}$; 7) paraquat at $0.28 \mathrm{~kg}$-ha-1 plus UAN at 3.8 liter $\cdot$ ha $^{-1}$; and (8) two applications of paraquat at $0.28 \mathrm{~kg} \cdot \mathrm{ha}^{-1}$. Treatments 2 to 7 also included X-77 Spreader (Chevron Chemical, Ortho Agricultural Chemical Div., Richmond, Calif.) at 470 $\mathrm{ml} \cdot \mathrm{ha}^{-1}$. Urea ammonium nitrate is a commercially available (Growmark, Bloomington, 111.) liquid fertilizer whose concentration is equivalent to $16.5 \mathrm{~kg} \mathrm{~N}$ per 100 liter. The adjuvant UAN has been reported to improve the activity of many postemergence herbicides (Beckett and Stoner, 1988). The desiccant rates were selected based on the minimum labeled rates for potato.

The first desiccant treatments were made on 11 July 1987 and 25 July 1988, when the onion sets started to senescence. In 1987, the onion leaves were lying on the soil surface 
and starting to brown, while in 1988 the onion leaves were lying on the soil surface but were still green. The second applications (treatments 5 and 8) were made 3 days later. Desiccants were applied with a $\mathrm{CO}_{2}$ backpack sprayer equipped with 8006 flat fan nozzles and delivering 370 liter $\cdot$ ha $^{-1}$ at 210 $\mathrm{kPa}$.

Desiccation of the onion shoots was rated 10 days after the first application on a scale of $0=$ no foliar bum or senescence to $100=$ complete foliar burn and tissue death . The bulbs were harvested and visually inspected for exterior damage. The shoots were cut from the bulbs, and the bulbs were sorted into either U.S. no. 1 or all others (Jones and Mann, 1963). The U.S. no. 1 bulbs were allowed to cure by passing dried air at ambient temperature over them for 3 weeks. All bulbs sorted as U.S. no. 1 were then stored at $5 \mathrm{C}$ for 4 months, after which they were resorted. Then, 12 U.S. no. 1 bulbs for each treatment-replicate combination were planted into 10 -cm-diameter $\left(480 \mathrm{~cm}^{2}\right)$ plastic pots containing an artificial medium [ 1 peat moss : 1 loam soil : 1 perlite (by volume)]. The onions began to emerge $\approx 2$ weeks after planting and continued to emerge for the next 3 weeks.

Data were tested by analysis of variance. There was no significant interaction between year and either treatment or cultivar, indicating that trends were similar both years; therefore, data from both years were combined for analysis. Means were separated by least significant difference procedure.

Desiccant treatment had no effect on yield of bulbs or the percent of bulbs graded as U.S. no. 1 immediately after harvest (data not shown). Yield was $\approx 15,000 \mathrm{~kg} \cdot \mathrm{ha}^{-1}$ and $\approx 85 \%$ of the bulbs were graded as U.S. no. 1. The main reason for rejection was small size. The bulbs had no apparent external injuries, were not misshapen, and were solid and healthy appearing after harvest.

Desiccation was less in 1988 than in 1987. For example, desiccation 10 days after treatment averaged 52\% in 1988 and $75 \%$ in 1987 . The difference between years was probably due to less-mature onions and hot and dry weather in 1988. Such weather can decrease bipyridinium herbicide absorption (Summers, 1980). Also, how far onion senescence has progressed before desiccant application appears to be important in obtaining satisfactory foliage kill.

Paraquat applied once desiccated $87 \%$ of 'White Portugal' onion shoots, making neither UAN nor a second application of paraquat necessary (Table 1). Including UAN with paraquat significantly improved desiccation of 'Red Wethersfield' compared to paraquat alone. 'Red Wethersfield' was more upright at the time of application than 'White Por- tugal', so contact and retention of the spray solution by foliage of 'Red Wethersfield' was probably poorer than for 'White Portugal'. Diquat applied once desiccated shoots of 'Red Wethersfield' $62 \%$ and those of 'White Portugal' $68 \%$. A second application of diquat or addition of UAN to the spray solution improved desiccation. Two applications of diquat are often required for complete desiccation of potato vines (Zandstra and Putnam, 1989). Lactofen at $0.56 \mathrm{~kg} \cdot \mathrm{ha}^{-1}$ caused slight phytotoxicity but did not desiccate onion shoots.

The percent of 'White Portugal' bulbs regraded U.S. no. 1 after 4 months of storage was reduced by paraquat, but not by diquat (Table 1). The reduction in quality was primarily due to the bulbs drying up. 'Red Wethersfield' was not as adversely affected by paraquat as was 'White Portugal'. The rapid kill of 'White Portugal' leaves by paraquat could have caused bulb damage or not allowed proper curing of the onion neck, Comin (1946) reported that if the neck region is not fully dried out it becomes a prime target for diseases.

Sprouting of 'Red Wethersfield' and 'White Portugal' bulbs differed. Sprouting 3 and 5 weeks after planting of 'Red Wethersfield' treated with diquat + UAN was reduced when compared to the control (Fig. 1). Diquat did not decrease sprouting of 'White Portugal'. Paraquat decreased sprouting of both cultivars compared to the control. For example, $<20 \%$ of bulbs had sprouted 5 weeks after planting when paraquat was applied once. The greatest difference in sprouting between cultivars was for bulbs harvested from onions treated twice with paraquat. Of 'White Portugal', $60 \%$ sprouted, while $8 \%$ of 'Red Wethersfield' sprouted. The shoots emerging in the paraquat treatments appeared to have reduced vigor. The difference in sprouting occurred both years and possibly was due to greater translocation of paraquat into 'Red Wethersfield' bulbs.

Germination of monocots has been reported to be affected by applications of paraquat (Appleby and Brenchley, 1968; Eagely and Williams, 1978; Klingman and Murray, 1976; Salazar and Appleby, 1982; Young et al., 1984) For seed germination or onion bulb sprouting to be affected, a significant amount of herbicide must be absorbed, translocated, and retained (Young et al., 1984). Injury to onion bulbs from bipyridinium herbicides could be related to high temperatures at the time of application causing rapid uptake and translocation into the bulb (Merkle et al., 1965; Jones and Mann, 1963). Necrosis at the stem end of potato tubers following the application of diquat was correlated with the amount of bipyridinium herbicide in the tubers (Eagely and Williams, 1978).
Diquat and paraquat applications affect sprouting of the bulbs, suggesting that the herbicides move into the bulb, possibly injuring the shoot meristem. Therefore, they are probably unsuited for foliar desiccation in set production.

\section{Literature Cited}

Appleby, A.P. and R.G. Brenchley. 1968. Influence of paraquat on seed germination. Weed Sci. 15:484-485.

Beckett, T.H. and E.W. Stoner. 1988. Fertilizer and adjuvant effects on quizalofop and DPXM6316 foliar uptake. N. Central Weed Control Conf. 43:4041.

Bishop, T., S.B. Powles, and G. Comic. 1987. Mechanism of paraquat resistance in Hordeum glaucum. II. Paraquat uptake and translocation. Austral. J. Plant Physiol. 14:539-547.

Comin, D. 1946. Onion production. Orange Judd, New York.

Eagely, G. H., and R.D. Williams. 1978. Glyphosate and paraquat effects on weed seed germination and seedling emergence. Weed Sci. 26:249-251.

Headford, D.W.R. and G. Douglas. 1987. Tuber necrosis following the desiccation of potato foliage with diquat. Weed Res. 7:131-144.

Hopen, H.J. and C.E. Peterson. 1974. Seeding rates, cultivars, and planting methods for small processing onions (Allium cepa L.). Res. Bul. 749, Agr. Expt. Sta., Univ. of Illinois, Urbana.

Jones, H.A. and L.K. Mann. 1963. Onions and their allies. Botany, cultivation and utilization. Interscience, New York.

Klingman, D.L. and J.J. Murray. 1976. Germination of seeds of turfgrasses as affected by glyphosate and paraquat. Weed Sci. 24:191-193.

Merkle, M. G., C.L. Leinweber, and R.W. Bovery. 1965. The influence of light, oxygen and temperature on the herbicidal properties of parsquat. Plant Physiol. 40:832-835.

Merritt, C.R. 1982. The influence of form of deposit on the phytotoxicity of MCPA, paraquat and glyphosate applied as individual droplets. Ann. Applied Biol. 101:527-532.

Nonnecke, LL. 1989. Vegetable production. Van Nostrand Reinhold, New York.

Salazar, L.C. and A.P. Appleby. 1982. Germination and growth of grasses and legumes from seedstreatedwithglyphosateandparaquat.Weed Sci. 30:235-237.

Summers, L.A. 1980. The bipyridinium herbicides. Academic, London.

Tanaka, Y., H. Chisaka, and H. Saka. 1986. Movement of paraquat in resistant and susceptible biotypes of Erigeron philadelphicus and E. canadensis. Physiol. Plant 66:605-608.

Walker, J. C., W.C. Edmundson, and H.A. Jones. 1944.Onionset production. Farmers' Bul. 1955. U.S. Dept. Agr.

Young, E. L., D.R. Gealy, and L.A. Morrow. 1984. Effect of herbicides on germination and growth of four grass weeds. Weed Sci. 32:489493.

Zandstra, B.H. and A.R. Putnam. 1989.1990 North central weed control guide for vegetable growers. N. Central Regional Publ. 330, Michigan State Univ., East Lansing. 